\title{
First record of Phoebis argante chincha Lamas (Lepidoptera, Pieridae) in Chile
}

\author{
Héctor A. Vargas ${ }^{1} \&$ Gerardo Lamas ${ }^{2}$
}

12Departamento de Recursos Ambientales, Facultad de Ciencias Agronómicas, Universidad de Tarapacá, Casilla 6-D, Arica, Chile. havargas@uta.cl
${ }^{2}$ Museo de Historia Natural, Universidad Nacional Mayor de San Marcos. Apartado 14-0434, Lima-14, Perú. glamasm@unmsm.edu.pe

\begin{abstract}
First record of Phoebis argante chincha Lamas (Lepidoptera, Pieridae) in Chile. The presence of Phoebis argante chincha Lamas, 1976 (Lepidoptera, Pieridae) is reported for the first time in Chile, from the Azapa valley, Arica.
\end{abstract}

KEYWORDS. Distribution; Inga feuillei; Phoebis sennae; taxonomy.

RESUMO. Primeiro registro de Phoebis argante chincha Lamas (Lepidoptera, Pieridae) no Chile. A presença de Phoebis argante chincha Lamas, 1976 (Lepidoptera; Pieridae) é mencionada pela primeira vez para o Chile, no vale de Azapa, Arica.

PALAVRAS-CHAVE. Distribuição; Inga feuillei; Phoebis sennae; taxonomia.

Species of the butterfly genus Phoebis Hübner, [1819] are distributed from southern Canada to Chile and Argentina, and throughout the Antilles (D'Almeida 1940). Phoebis argante (Fabricius, 1775) has been reported from many localities of continental America and Antilles (e.g. D'Almeida 1940; Monroe et al. 1967; Brown \& Mielke 1968; Lamas 1976b; Salinas-Gutiérrez et al. 2004; Maes 2007). Seven valid subspecies are recognized along its extensive geographical range (Lamas 2004), one of them being $P$. argante chincha Lamas, 1976, occurring along western Ecuador and Peru. The presence of this subspecies in northern Chile is reported herein for the first time.

Adults of $P$. argante chincha were initially observed during February 2009 in the Azapa valley, Arica province, Chile, flying in the vicinity of "pacay" trees (Inga feuillei D.C., Fabaceae). Subsequently, many larvae were found eating the leaves of the trees. Some larvae were collected, taken to the laboratory, and enclosed in glass rearing vials, where leaves were changed daily until pupation. Pupae were observed periodically in order to obtain adults for taxonomic identification (Figs. 1-4).

Until now, the southern distributional limit of $P$. argante chincha was known to be the department of Tacna, Peru, adjacent to the province of Arica, Chile, and its single known larval hostplant was reported to be Inga feuillei (Hughes 1958; Lamas 1976a, b). Several Phoebis species are well-known migrants (Williams 1930), including $P$. argante (Oliveira et al. 1998). Inga feuillei is not a native plant of northern Chile, being introduced in the country due to the importance of its fruits as human food (Brennan \& Mudge 1998). Thus, the presence of $P$. argante chincha in northern Chile should be regarded as a very recent colonisation event. Apparently, the ca. $50 \mathrm{~km}$-wide area of hyper-arid coastal desert separating the valleys of Tacna and Azapa was an effective barrier in the past, preventing the southward dispersal of $P$. argante chincha, or else the lack of a suitable larval hostplant did not allow establishment of the butterfly in the latter area.

Two other examples of butterflies with immature stages associated with exotic plants in Chile, which are now represented by resident breeding populations in the northern part of the country, are the hesperiids Calpodes ethlius (Stoll, 1782) (Vargas et al. 2006) and Quinta cannae (HerrichSchäffer, 1869) (Etcheverry 1970).

Additional field observations will be necessary to determine if $P$. argante chincha is a new permanent resident butterfly in northern Chile, or if its presence is temporary, possibly associated with periodic southern migrations/range expansions.

The only species of Phoebis previously reported in Chile is $P$. sennae amphitrite (Feisthamel, 1839) (Peña \& Ugarte 1996). Thus, $P$. argante chincha is the second representative of this genus occurring in this country. Both species may be easily separated by their different wing maculation. Moreover, the distribution area of $P$. sennae amphitrite in Chile is restricted to the central zone (Peña \& Ugarte 1996), not reaching the Arica province.

The Chilean specimens examined in this study will be deposited in the Museo Nacional de Historia Natural de Santiago (MNNC), Santiago, Chile.

Material examined. CHILE, Arica. 2 males, 1 female: Azapa, Arica, Chile, March 2009, reared from larva on Inga feuillei, 

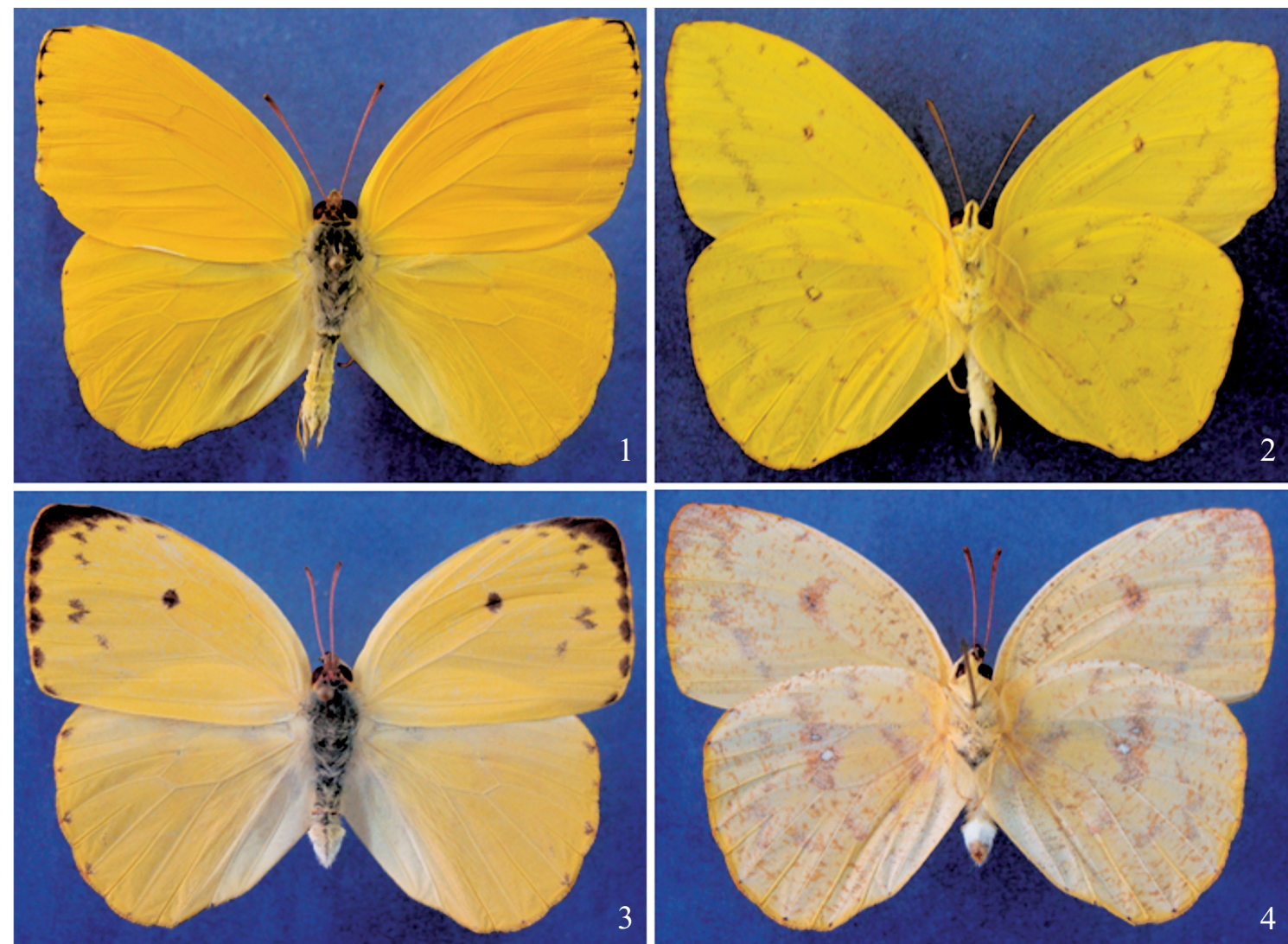

Fig. 1-4. Adults of Phoebis argante chincha reared from larvae collected on Inga feuillei in the Azapa valley, northern Chile. 1-2, Male, dorsal and ventral surfaces, respectively; $3-4$, Female, dorsal and ventral surfaces, respectively.

February 2009, H.A. Vargas coll.; 1 female: Azapa, Arica, Chile, May 2009, reared from larva on Inga feuillei, April 2009, H. A. Vargas coll. (MNNC).

\section{ACKNOWLEDGEMENTS}

This study was supported by project DIEXA-UTA 9710-10.

\section{REFERENCES}

Brennan, E. B. \& K. W. Mudge. 1998. Vegetative propagation of Inga feuillei from shoot cuttings and air layering. New Forests 15: 37-51.

Brown, K. S. Jr. \& O. H. H. Mielke. 1968. Lepidoptera of the Central Brazil Plateau. III. Partial list for the Belo Horizonte area, showing the character of the south-eastern "blend zone". Journal of the Lepidopterists' Society 22: 147-157.

D’Almeida, R. F. 1940. Revisão do gênero Phoebis Hübn. (Lepidopt. Pierididae). Arquivos de Zoologia do Estado de São Paulo 1: 67152

Etcheverry, M. 1970. Quinta cannae (Herrich-Schäffer) 1869 género y especie de Hesperiinae nuevo para Chile (Hesperiidae, Lepidoptera). Publicaciones del Centro de Estudios Entomológicos 10: 19-22.

Hughes, R. A. 1958. Migrant butterflies along the Peruvian coast. Entomologist 91: 181-187.

Lamas, G. 1976a. Mariposas diurnas (Lepidoptera, Rhopalocera) que atacan plantas de interés agrícola en el Perú. Revista Peruana de Entomología 18: $1-5$.

Lamas, G. 1976b. Notes on Peruvian butterflies (Lepidoptera). I. The genus Phoebis Hübner, 1819 (Pieridae), with the description of a new subspecies. Revista Peruana de Entomología 18: 5-9.

Lamas, G. 2004. Pieridae, p. 99-117. In: G. Lamas (Ed.). Checklist: Part 4A. Hesperioidea - Papilionoidea. In: J. B. Heppner (Ed.), Atlas of Neotropical Lepidoptera. Volume 5A. Gainesville, Association for Tropical Lepidoptera; Scientific Publishers.

Maes, J.-M. 2007. Pieridae (Lepidoptera) de Nicaragua. Revista Nicaragüense de Entomología, Suplemento 1, 313 p.

Monroe, R. S.; G. N. Ross \& R. N. Williams. 1967. A report on two recent collections of butterflies from Honduras. Journal of the Lepidopterists' Society 21: 185-197.

Oliveira, E.G.; R. B. Syrgley \& R. Dudley. 1998. Do neotropical migrant butterflies navigate using a solar compass? Journal of Experimental Biology 201: 3317-3331.

Peña G., L. E. \& A. J. Ugarte P. 1996. Las mariposas de Chile. The butterflies of Chile. Santiago, Editorial Universitaria, 359 p.

Salinas-Gutiérrez, J.L., A. Luis-Martínez \& J. Llorente-Bousquets. 2004. Papilionoidea of the evergreen tropical forests of Mexico. Journal of the Lepidopterists' Society 58: 125-142.

Vargas, H. A.; O. H. H. Mielke \& M. M. Casagrande. 2006. Calpodes ethlius (Stoll, 1786): primer registro de distribución para el extremo norte de Chile. Idesia 24: 69-70.

Williams, C. B. 1930. The migration of butterflies. Edinburgh \& London, Oliver \& Boyd, 473 p.

Received 19/1/2011; accepted 26/7/2011

Editor: Marcelo Duarte 